University of Nebraska - Lincoln

DigitalCommons@University of Nebraska - Lincoln

1994

\title{
Thorium-230 Ages of Corals and Duration of the Last Interglacial Sea-Level High Stand on Oahu, Hawaii
}

\author{
Barney J. Szabo \\ U.S. Geological Survey \\ Kenneth R. Ludwig \\ U.S. Geological Survey \\ Daniel R. Muhs \\ U.S. Geological Survey, dmuhs@usgs.gov \\ Kathleen R. Simmons \\ U.S. Geological Survey, ksimmons@usgs.gov
}

Follow this and additional works at: https://digitalcommons.unl.edu/usgsstaffpub

Part of the Earth Sciences Commons

Szabo, Barney J.; Ludwig, Kenneth R.; Muhs, Daniel R.; and Simmons, Kathleen R., "Thorium-230 Ages of Corals and Duration of the Last Interglacial Sea-Level High Stand on Oahu, Hawaii" (1994). USGS Staff -Published Research. 185.

https://digitalcommons.unl.edu/usgsstaffpub/185

This Article is brought to you for free and open access by the US Geological Survey at DigitalCommons@University of Nebraska - Lincoln. It has been accepted for inclusion in USGS Staff -- Published Research by an authorized administrator of DigitalCommons@University of Nebraska - Lincoln. 


\title{
Thorium-230 Ages of Corals and Duration of the Last Interglacial Sea-Level High Stand on Oahu, Hawaii
}

\author{
Barney J. Szabo, ${ }^{\star}$ Kenneth R. Ludwig, Daniel R. Muhs, \\ Kathleen R. Simmons
}

Thorium-230 ages of emergent marine deposits on Oahu, Hawaii, have a uniform distribution of ages from $\sim 114,000$ to $\sim 131,000$ years, indicating a duration for the last interglacial sea-level high stand of $\sim 17,000$ years, in contrast to a duration of $\sim 8000$ years inferred from the orbitally tuned marine oxygen isotope record. Sea level on Oahu rose to $\geq 1$ to 2 meters higher than present by 131,000 years ago or $\sim 6000$ years earlier than inferred from the marine record. Although the latter record suggests a shift back to glacial conditions beginning at $\sim 119,000$ years ago, the Oahu coral ages indicate a near present sea level until $\sim 114,000$ years ago.

The peak of the last interglacial period (marine oxygen isotope substage $5 \mathrm{e}$ ) has been considered to be a possible analog for a future greenhouse climate resulting from the buildup of $\mathrm{CO}_{2}$ and other gases (1). Estimates for the timing [peak at $\sim 125$ thousand years ago $(\mathrm{ka})]$ and duration $(\sim 8$ $\times 10^{3}$ years) of the last interglacial have been derived mainly from an orbitally tuned $\delta^{18} \mathrm{O}$ chronology of deep-sea cores, SPECMAP (2-4). If the oxygen isotopic composition of seawater is controlled principally by changes in global ice volume, the $\delta^{18} \mathrm{O}$ variation in foraminifera provides a proxy record for changes in global sea level (5). However, from U-series ages of calcite at Devils Hole, Nevada $(6,7)$, Winograd et al. (7) inferred that the last interglacial began earlier $(\sim 140 \mathrm{ka})$ and lasted longer $(\sim 20 \times$ $10^{3}$ years) than the SPECMAP $\delta^{18} \mathrm{O}$ record indicates. This result challenges the orbitalforcing theory of Milankovitch as being the primary trigger for major climatic changes that occurred during the Pleistocene (7).

Emergent fossil coral reefs on tectonically stable coasts provide a geologic record of a higher-than-present sea level during the last interglaciation. If a coral reef grows vertically, responding to a rising interglacial sea, then high-precision U-series dating of suitable coral samples can potentially reveal the timing of sea-level rise during an interglacial (8). In this study, we report ages of fossil corals from Oahu and use these results to ascertain the timing and duration of the last interglacial period.

Well-preserved coral reefs or coral-bearing marine deposits fringe much of Oahu (Fig. 1). We collected and analyzed samples of Porites sp. and Pocillopora sp. (both frequently found in typical shallow-water habitats of reefs) at 19 localities (Fig. 1) (9).

U.S. Geological Survey, Denver Federal Center, Mail Stop 963, Box 25046, Denver, CO 80225, USA.

*To whom correspondence should be addressed.
Most last interglacial marine deposits on Oahu are gently dipping, generally wellsorted and well- to poorly cemented, coralbearing conglomerate. We observed and collected corals in growth position only in deposits near Mokapu Point and Kahuku Point and at exposures of a reef east of Kaena Point (Fig. 1) (10).

Two tests for the reliability of U-series coral ages are that $\mathrm{U}$ concentrations should fall within the range of modern corals and that calculated initial ${ }^{234} \mathrm{U} /{ }^{238} \mathrm{U}$ activity ratios in fossil corals should be close to that of modern seawater (8). Modern seawater has a ${ }^{234} \mathrm{U} / 238 \mathrm{U}$ ratio of $1.148 \pm 0.002$ (11). We classify fossil corals with calculated initial ${ }^{234} \mathrm{U} /{ }^{238} \mathrm{U}$ ratios in this range as category A samples and consider that their ${ }^{230} \mathrm{Th} /{ }^{238} \mathrm{U}$ ages are reliable (Table 1). Category $B$ samples have initial ${ }^{234} \mathrm{U} /{ }^{338} \mathrm{U}$ ratios from 1.150 to 1.160 (as much as $1.0 \%$ higher than modern seawater) and are moderately reliable (accurate to within $<2000$ years) $(8,12,13)$. Ages of samples with ${ }^{234} \mathrm{U} / 238 \mathrm{U}$ ratios greater than 1.160 are unreliable because of the likelihood of a significant open-system history for $\mathrm{U}$ (and possibly $\mathrm{Th}$ ). Of the 33 last interglacial

samples that we analyzed, 17 are category A, 12 are category B (below the 1.16 curve in Fig. 2), and 4 are unreliable and not discussed further.

Growth-position corals from $\sim 7.3 \mathrm{~m}$ above sea level at Mokapu Point yielded ages of $129.9 \pm 1.5$ and $131.0 \pm 2.7 \mathrm{ka}$, and corals from $\sim 8.6 \mathrm{~m}$ above sea level have ages of $125.0 \pm 3.8$ and $123.2 \pm 2.6 \mathrm{ka}$ (uncertainties are $2 \sigma$ ). Growth-position corals from 1 to $3 \mathrm{~m}$ above sea level at Kahuku Point yielded ages of $120.3 \pm 2.5$, $122.1 \pm 1.3$, and $121.7 \pm 1.5 \mathrm{ka}$, and two corals from east of Kaena Point, between 1 and $3 \mathrm{~m}$ above sea level, yielded ages of $110.5 \pm 3.8$ and $114.8 \pm 2.1 \mathrm{ka}$. From these age determinations, we estimate that the apparent local paleosea level was at least 7 $\mathrm{m}$ higher than at present by $\sim 130 \mathrm{ka}$ and remained higher until at least $\sim 115 \mathrm{ka}$. Because living Porites and Pocillopora occupy a considerable depth range (1 to $27 \mathrm{~m}$ below sea level), all of our paleosea level estimates on growth-position corals are minima.

The distribution of coral ages between about 131 and $114 \mathrm{ka}$ is fairly uniform (Fig. 3) (14). These results indicate that the last interglacial sea-level high stand lasted $\sim 17,000$ years, in contrast to a duration of $\sim 8000$ years estimated from the SPECMAP record. Six of our coral ages (three category A and three category B samples, including two collected at growth position) are significantly older than the time of a major insolation high at $\sim 127 \mathrm{ka}(15)$. These ages imply that the sea-level high predated the insolation maximum by at least 4000 years. Four category A (including two samples in growth position) and two category $B$ corals have ages between $\sim 111$ and $115 \mathrm{ka}$ and imply that the last interglacial sea was high at this time. In contrast, the orbital forcing theory predicts a major insolation low at $116 \mathrm{ka}(15,16)$, and the SPECMAP chronology indicates that sea level was 20 to $50 \mathrm{~m}$ lower than at present (2-5). Thus, the Oahu record implies that

Fig. 1. Distribution of emergent coral reefs of Oahu (darkened areas) from (25) [for the east Kaena Point area distribution, see (10)], and localities of dated Quaternary deposits referred to in the text. Abbreviations: $\mathrm{DH}$, Diamond Head; BP, Black Point; MRP, Makai Range Pier; AP, Alala Point; MP, Mokapu Point; KAH, Kahuku Point; MB, Mokuleia Beach; EKP, East Kaena Point Reef; KP, Kaena Point; SKP, Southeast Kaena Point Reef; KSP, Kaena Point State Park; and KAP, Kahe Point. Sample localities are shown in parentheses (see Table 1).

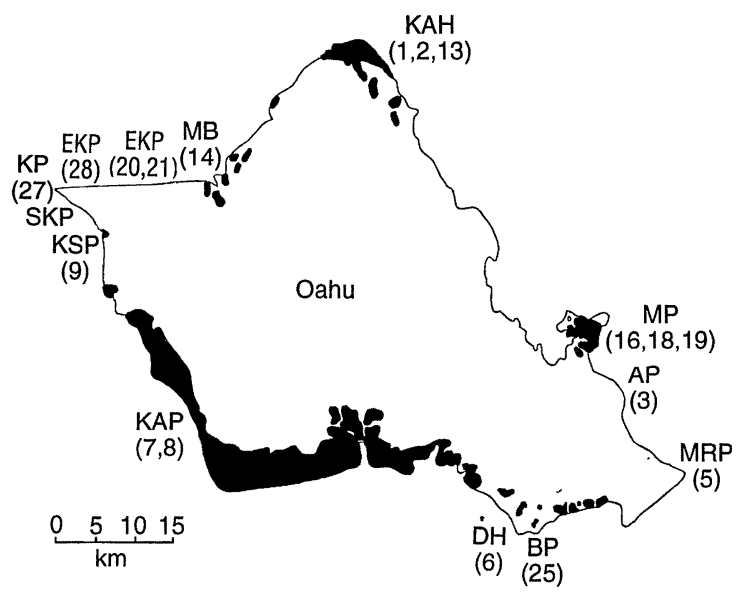


sea-level changes during the last interglacial were not controlled entirely by cyclic variations in insolation parameters (17). The U-series ages of fossil coral reefs in the Bahamas, Haiti, Barbados, New Guinea, Vanuatu, and at the margin of southwestern Australia $(8,12,13,18,19)$ also suggest that last interglacial reefs were well established no later than $131 \mathrm{ka}$.

We have not observed (10) stratigraphic evidence for two episodes of high sea level on Oahu during the last interglacial period, as hypothesized (20) on the basis of a bimodal distribution of the previously reported coral ages (9) and stratigraphic interpretations supported by a limited number of electron spin resonance and $\alpha$-spectrometric U-series ages (21). If two high sea-level stands had occurred on Oahu, then the intervening decline of the sea could not have lasted significantly longer than $\sim 2000$ years, on the basis of the rather uniform distribution of coral age measurements with overlapping analytical uncertainties (Fig. 3).
Table 1. Isotopic and age data for Oahu coral samples. Ratios are activity ratios calculated from the atomic ratios. Errors are shown in parentheses, at the $2 \sigma$ level, for the least significant digits. We calculated the ages using half-lives from ${ }^{230} \mathrm{Th}$ and ${ }^{234} \mathrm{U}$ of 75,380 and 244,600 years, respectively (27); the calculated ages include a negligible to very small correction for initial detrital Th and $U$ with assumed activity ratios for ${ }^{234} \mathrm{U} / 238 \mathrm{U}$, ${ }^{230} \mathrm{Th} /{ }^{238} \mathrm{U}$, and ${ }^{232} \mathrm{Th} /{ }^{238} \mathrm{U}$. of $1.0 \pm 0.3,1.0 \pm 0.3$, and $1.21 \pm 0.64$, respectively.

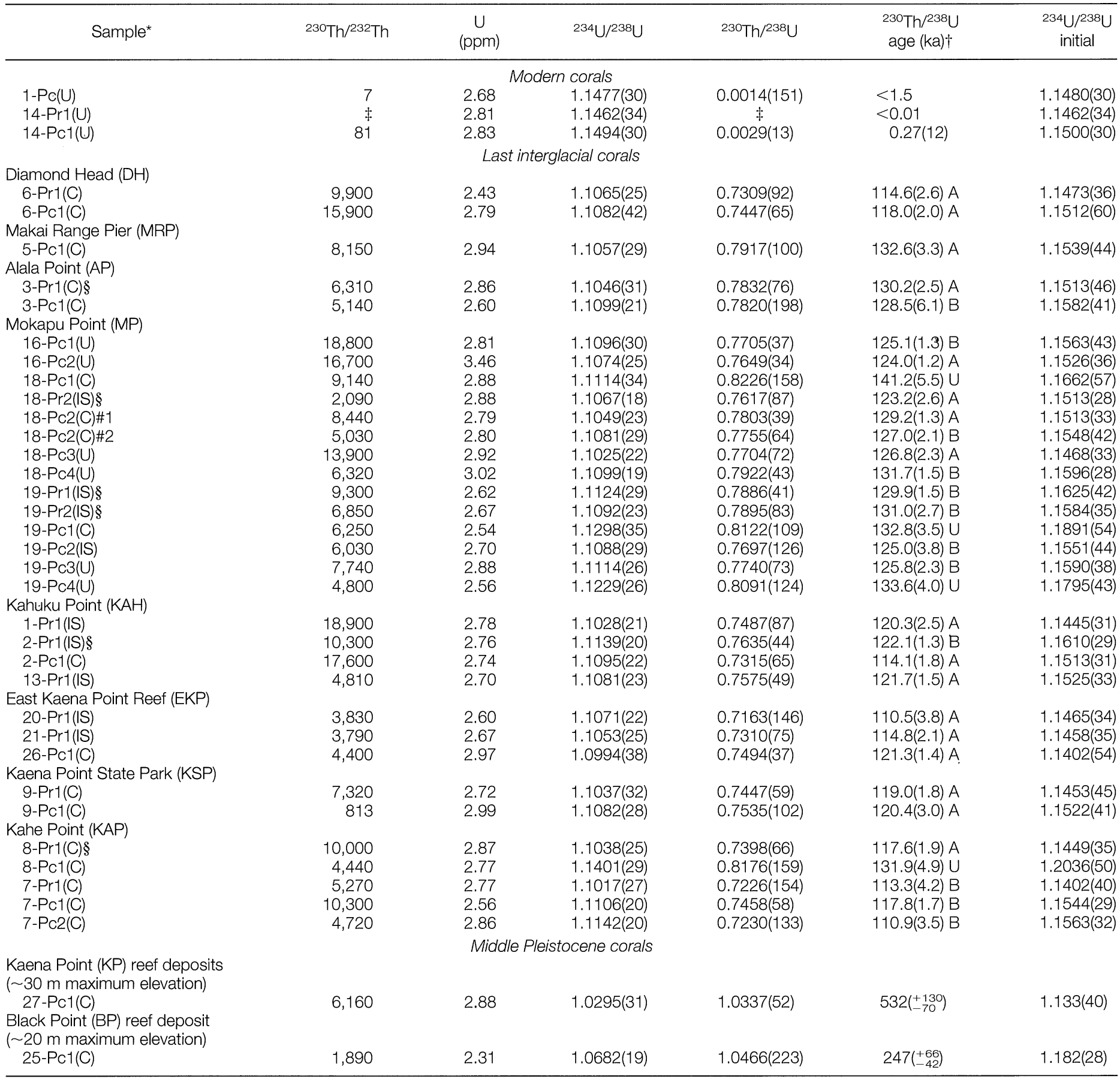

*Sample names include locality number as shown in Fig. 1 (first number); coral genus ( $\mathrm{Pr}=$ Porites sp., Pc = Pocillopora sp.), sample number, and stratigraphic setting (IS = in situ, $\mathrm{C}=$ lithified conglomerate, and $\mathrm{U}=$ unlithified conglomerate) in parentheses. Samples were $\geq 99 \%$ aragonite unless otherwise noted. †Ages of the last interglacial corals are classified as reliable $(A)$, moderately reliable $(B)$, or unreliable $(U)$, on the basis of their calculated initial ${ }^{234} \mathrm{U} / 238 \mathrm{U}$ ratio (see text). $\$ \mathrm{NNo}^{230} \mathrm{Th}$ resolved; ${ }^{232} \mathrm{Th}=0.74$ parts per billion. $\quad \S$ Sample was between 95 and 99\% aragonite; remainder was calcite. 
Stearns (22) described emergent marine deposits $(\sim 30 \mathrm{~m}$ maximum elevation above present sea level) near and southeast of Kaena Point and a marine deposit ( $\sim 20 \mathrm{~m}$ above present sea level) overlain by basalt near Black Point (Fig. 1). He proposed that these deposits are evidence for large glacio-eustatic sea-level fluctuations during the middle Pleistocene. Field studies of tectonically stable coastlines have failed to reveal the presence of any Pleistocene marine deposits higher than $\sim 10 \mathrm{~m}$, and these observations are sup- ported by reasonable estimates of sea-level rise associated with ice-sheet melting (10).

We propose instead that Oahu was uplifted during the Quaternary and collected coral samples to determine an average uplift rate $(23)$. Of six samples from before the last interglacial, only two yielded finite ${ }^{230} \mathrm{Th} /{ }^{238} \mathrm{U}$ ages and acceptable back-calculated initial ${ }^{234} U{ }^{238} \mathrm{U}$ values (Table 1). A coral sample from the Kaena Limestone now exposed $24.4 \mathrm{~m}$ above sea level gave an age of $532\left({ }_{-70}^{+130}\right) \mathrm{ka}$. A probable correlation
Fig. 2. Diagram showing $U$-Th evolution for last interglacial corals from Oahu (Table 1). Analyses are shown by their $2 \sigma$ error ellipses (main diagram) or, without error information, as circles (inset). Curved lines are isotopic evolution paths for various initial ${ }^{234} \mathrm{U} /$ ${ }^{238} \mathrm{U}$ values $\left(=\gamma_{0}\right)$. The cross-hatched band (1.148 \pm 0.002$)$ denotes the area of category $A$ samples (ages of high reliability). Samples that plot within the range of $1.155 \pm 0.005$ and sample $7-\operatorname{Pr} 1(C)$ are category $B$ type (ages of moderate reliability). Samples with ${ }^{234} \mathrm{U} / 238 \mathrm{U}>1.160$ are considered unreliable (see text). Oblique dotted lines are isochrons in thousands of years.

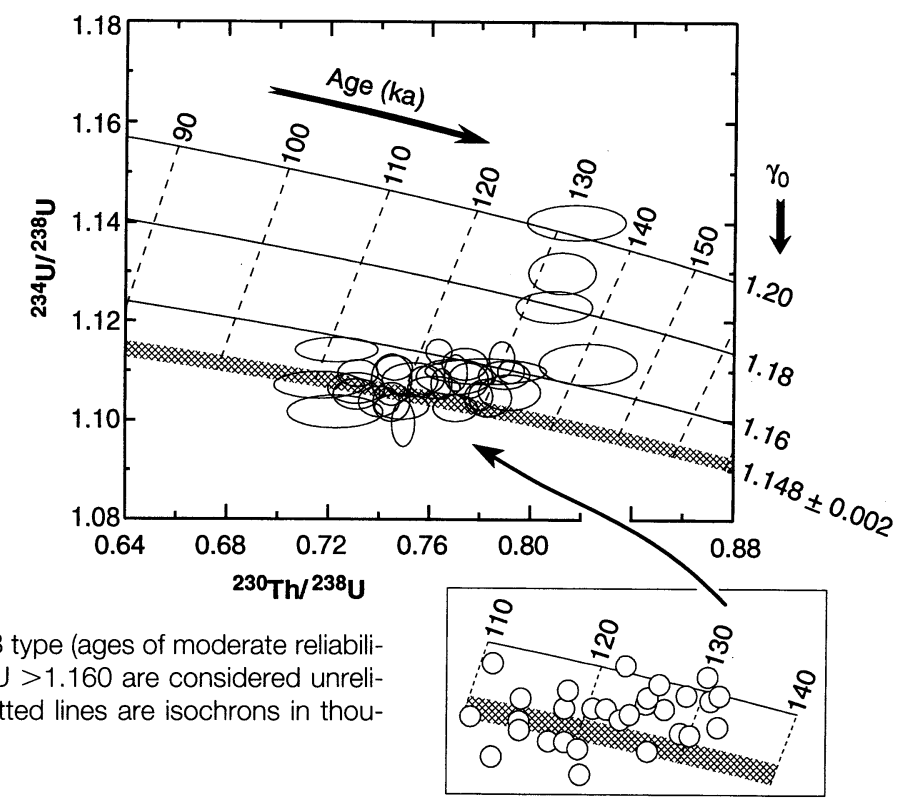

Fig. 3. Plot of part of the SPECMAP orbitally tuned deep-sea oxygen isotope record, where peaks in the $\delta^{18} \mathrm{O}$ record indicate interglacial and high sea-level conditions. The lower curve shows the variation of insolation at the top of the atmosphere for June at $60^{\circ} \mathrm{N}$ (15). The dashed vertical line shows the time of a major insolation high at $\sim 128 \mathrm{ka}$ (warm climate and reduction of continental ice volume); the dotted vertical line shows the time of a major insolation low at 116 ka (cold climate and building up of ice vol-

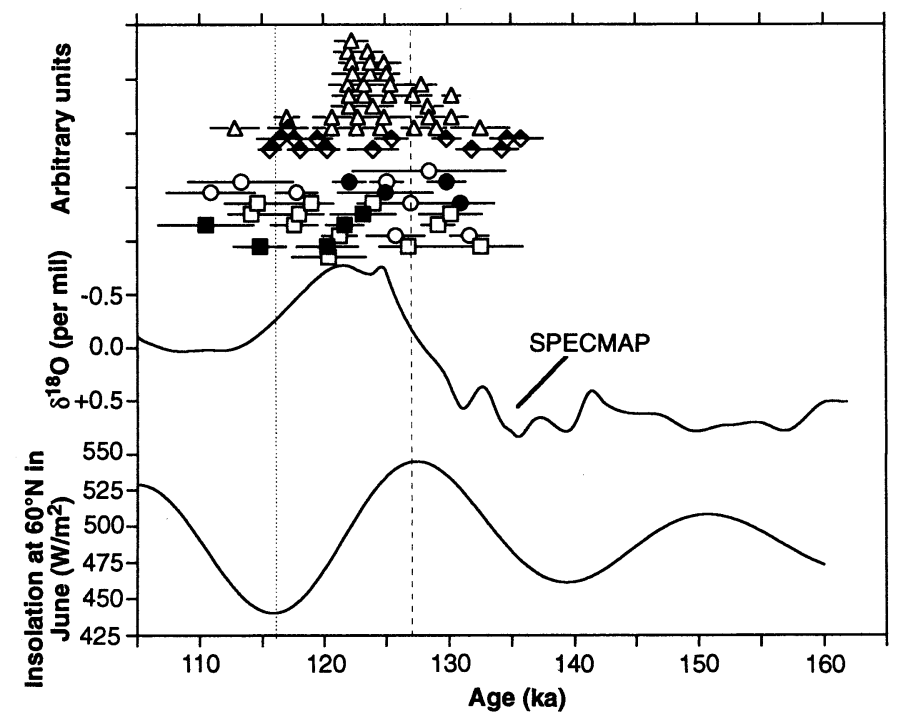

ume). The ${ }^{230} \mathrm{Th} /{ }^{238} \mathrm{U}$ ages of last interglacial Oahu corals are presented in the upper left of the figure. Solid and open squares represent category $A$ ages of corals (initial ${ }^{234} \mathrm{U} /{ }^{238} \mathrm{U}$ suggesting ages of high reliability) from growth position and conglomerate facies, respectively. Solid and open circles represent category $\mathrm{B}$ ages of corals (initial ${ }^{234} \mathrm{U} / 238 \mathrm{U}$ suggesting ages of moderate reliability) from growth position and conglomerate facies, respectively. Category $A$ and category $B$ high-precision $U$-series ages of fossil corals from New Guinea, Vanuatu, and southwestern Australia (partially shaded diamonds) $(12,18,19)$ and from the Bahamas, Haiti, and Barbados (open triangles) $(8,13,19,26)$ are also shown. Horizontal bars indicate $2 \sigma$ uncertainties of each age. of the sample is to sea-level high stands recorded as either deep-sea oxygen isotope stage $15(\sim 550 \mathrm{ka})$ or stage $13(\sim 470 \mathrm{ka})$. From these age estimates and an assumption of a paleosea level close to the present, we calculate long-term average uplift rates of 0.05 to $0.06 \mathrm{~m}$ per $10^{3}$ years. A coral from the Black Point Limestone now exposed $\sim 17 \mathrm{~m}$ above sea level yielded an age of $347\left(\left(_{-42}^{+66}\right) \mathrm{ka}\right.$. The $\mathrm{K}-\mathrm{Ar}$ ages of overlying basalt and an associated dike are $480 \pm 160$ and $410 \pm 80 \mathrm{ka}$, respectively; the age of the dike is considered to be the best estimate for both the dike and the flow (24). A probable correlation of the Black Point deposit is to oxygen isotope stage 11 $(\sim 410 \mathrm{ka})$, yielding an average uplift rate of $\sim 0.05 \mathrm{~m}$ per $10^{3}$ years. Assuming that these age estimates are reasonable and that Oahu experienced Quaternary uplift [a possible cause of uplift is discussed in (10)], we believe that the uplift-corrected minimum elevation of the last-interglacial sea level, based on the coral ages at Mokapu Point, is between +1 and $+3 \mathrm{~m}$.

If our age results are accurate, then the marine oxygen isotope record may not represent an ideal ice volume or sea-level record. Our observations thus are not consistent in any simple way with the orbitalforcing theory of climate change, and they add to a growing body of last-interglacial ages (Fig. 3) that suggest that revision in this theory is required to include consideration of the effects of other physical mechanisms acting in addition to, or coupled with, the orbital-forcing parameters.

\section{REFERENCES AND NOTES}

1. J. Hansen et al., J. Geophys. Res. 93, 9341 (1988).

2. J. D. Hays, J. Imbrie, N. J. Shackleton, Science 194, 1121 (1976).

3. J. Imbrie et al., in Milankovitch and Climate, A. Berger, J. Imbrie, J. Hays, G. Kukla, B. Saltzman Eds. (Reidel, Boston, 1984), part 1, pp. 269-305.

4. D. F. Williams et al., Palaeogeogr. Palaeoclimatol. Palaeoecol. 64, 221 (1988).

5. A change of 0.1 per mil in $\delta^{18} \mathrm{O}$ is considered equivalent to $\mathrm{a} \sim 10 \mathrm{~m}$ change in sea level [R. G. Fairbanks and R. K. Matthews, Quat. Res. 10, 181 (1978)].

6. K. R. Ludwig et al., Science 258, 284 (1992)

7. I. J. Winograd et al., ibid., p. 255.

8. J. H. Chen, H. A. Curran, B. White, G. J. Wasserburg, Geol. Soc. Am. Bull. 103, 82 (1991).

9. T.-L. Ku, M. A. Kimmel, W. H. Easton, T. J. O'Neil [Science 183, 959 (1974)] reported $\alpha$-spectrometric $U$-series ages from Oahu corals and indicated that the last interglacial sea stood apparently $\sim 7.6 \mathrm{~m}$ higher than today and occurred about $120 \mathrm{ka}$. The elevation estimate of this paleoshoreline is based on two undated notches cut in eolianite. An average value of $7.6 \mathrm{~m}$ is quoted because the two levels cannot be distinguished in most localities $[H$. T. Stearns, Geol. Soc. Am. Bull. 46, 178 (1935)]. Mineralogy of the corals was determined by $x$-ray diffraction analysis. Most of the samples were $\geq 99 \%$ aragonite. Six samples had 1 to $5 \%$ calcite (Table 1) resulting from the aragonite-to-calcite transformation, but there is no correlation between the unreliable results and calcite impurities. The dense, unrecrystallized parts of selected 3- to 6-g samples were broken into smaller fragments $(<0.6 \mathrm{~mm})$ and scrubbed in an ultrasonic water bath. The fragments 
were inspected under $\times 10$ magnification, and 200 to $300 \mathrm{mg}$ were selected for the mass spectrometric analyses. Details of the chemical and instrumental procedures were reported in (6)

10. Stratigraphic sections are presented by D. R. Muhs and B. J. Szabo [Mar. Geol. 118, 315 (1994)]. The normal tidal range of Oahu is $<0.8 \mathrm{~m}$, and modern coral reefs in protected bays grow upward to $\sim 0.5 \mathrm{~m}$ below low tide level.

11. R. L. Edwards et al. [Science 260, 962 (1993) reported that the variation in the initial ${ }^{234} \mathrm{U} / 238 \mathrm{U}$ activity value in 20 young ( 1.8 to $13.1 \mathrm{ka}) \mathrm{New}$ Guinea corals did not exceed 2 per mil, or $1.150 \pm$ 0.002 ( $2 \sigma$ of population). Our measurements of 16 young (modern to $16 \mathrm{ka}$ ) Florida and Hawaii corals yield a value of $1.148 \pm 0.002$ ( $2 \sigma$ of the mean) ( $K$ R. Ludwig, K. R. Simmons, D. R. Muhs, B. J. Szabo, unpublished data). For the purpose of this report, we specify an acceptable range of variation for initial ${ }^{234} \mathrm{U} / 238 \mathrm{U}$ of 1.146 to 1.150 . The range of $\mathrm{U}$ concentrations of the Oahu corals is 2.31 to $3.96 \mathrm{ppm}$, and the range of $U$ concentrations in young Hawaiian corals $(<15 \mathrm{ka})$ is 2.39 to 3.15 ppm [K. R. Ludwig, B. J. Szabo, J. G. Moore, K. R. Simmons, Geology 19, 171 (1991); this report]; we do not have large deviations indicative of an open system. All of the fossil Oahu corals have ${ }^{230} \mathrm{Th}$ ${ }^{232}$ Th activity ratios of $>800$, indicating that the samples should be free of inherited ${ }^{230}$ Th from detrital materials. However, we cannot rule out the possibility that a minute amount of ${ }^{230} \mathrm{Th}$, derived from dissolution of existing nearby coral, may have been incorporated into some of our samples, causing the calculated ages to be too old.

12. M. Stein et al., Geochim. Cosmochim. Acta 57, 2541 (1993).

13. C. D. Gallup, R. L. Edwards, R. G. Johnson, Science 263, 796 (1994). According to their model, category $B$ equivalent ages are accurate to within $<2000$ years.

14. Arbitrary age estimates based on the observation that the apparently sharp cutoff in all category $A$ and category B ages at about 131 and $114 \mathrm{ka}$, respectively, is about what one would expect for a true range of 131 to $114 \mathrm{ka}$, allowing for some dispersion at the extremes from analytical error.

15. A. L. Berger, Quat. Res. 9, 139 (1978); M. F. Loutre, Quat. Sci. Rev. 10, 297 (1991).

16. D. Rind, D. Peteet, G. Kukla, J. Geophys. Res. 94 (no. D10), 12851 (1989). Climate modeling experiments using the most favorable insolation variations have also failed to predict that snow cover could be maintained or the growth of major ice sheets initiated at northern latitudes, despite the major reduction in insolation culminating at $116 \mathrm{ka}$.

17. Unexplained aspects associated with the $10^{5}$-year cycle responding to the orbital climate forcing are examined by J. Imbrie et al. [Paleoceanography $\mathbf{8}$, 699 (1993)], and the internal response to orbital forcing is discussed by N.-A. Mörner [in Orbital Forcing and Cyclic Sequences, P. L. de Boer and D. G. Smith, Eds. (Special Publication of the International Association of Sedimentologists, Blackwell Scientific, Oxford, 1994), no. 19, pp. 25-33]. Changes in the Earth's geoid may have affected local paleosea level conditions [K. Lambeck and M. Nakada, Nature 357 125 (1992); A. Eisenhauer et al., Earth Planet. Sci. Lett. 114, 529 (1993)]

18. L. B. Collins et al., Mar. Geol. 110, 203 (1993); Z R. Zhu et al., Earth Planet. Sci. Lett. 118, 281 (1993).

19. R. L. Edwards, J. H. Chen, T.-L. Ku, G. J. Wasserburg, Science 236, 1547 (1987); B. Hamelin, E. Bard, A. Zindler, R. G. Fairbanks, Earth Planet. Sci. Lett. 106, 169 (1991)

20. C. E. Stearns, Quat. Res. 6, 445 (1976); J. Chappell and H. H. Veeh, Geol. Soc. Am. Bull. 89, 356 (1978); P. L. Smart and D. A. Richards, Quat. Sci. Rev. 11 687 (1992).

21. C. E. Sherman et al., Geology 21, 1079 (1993)

22. H. T. Stearns, Bernice P. Bishop Mus. Bull. 237, 1 (1978); Geology of the State of Hawaii (Pacific Books, Palo Alto, CA, 1966).

23. Large submarine landslides have been mapped adjacent to the islands of Hawaii including Oahu [ $\mathrm{J}$ G. Moore, W. R. Normark, R. T. Holcomb, Science 264, 46 (1994); J. G. Moore et al., J. Geophys.
Res. 94, 17465 (1989)]. Some of these debris avalanches may have produced giant wave deposits on the coastal slopes of Molokai and Lanai [J. G. Moore, W. B. Bryan, K. R. Ludwig, Geol. Soc. Am. Bull. 106, 962 (1994); J. G. Moore and G. W. Moore, Science 226, 1312 (1984)]. We studied the exposures of the $\sim 30-\mathrm{m}$ Kaena reef deposits about $3 \mathrm{~km}$ southeast of Kaena Point (SKP in Fig 1) and found no sedimentological characteristics that suggest an origin from a giant wave. Furthermore, morphologic analysis of nick points on interfluves suggests the existence of a former shoreline with a mean elevation of about $28 \mathrm{~m}[\mathrm{R}$. V. Ruhe, J. M. Williams, E. L. Hill, J. Geol. 73, 485 (1965)]

24. M. A L anphere and G. B. Dalrymple, Am I Sci. A 280, 736 (1980); H. T. Stearns and G. B. Dalrymple, Bernice P. Bishop Mus. Occas. Pap. 24, 307 (1978). 25. H. T. Stearns, Geol. Soc. Am. Bull. 85, 795 (1974).
26. E. Bard, B. Hamelin, R. G. Fairbanks, Nature 346, 456 (1990).

27. P. de Bièvre et al., in Proceedings of the International Conference on Chemical and Nuclear Data: Measurements and Applications, M. L. Hurrell, Ed. (Institute of Civil Engineers, London, 1971), pp. 211-225; J. W. Meadows, R. J. Armani, E. L. Callis, A. M. Essling, Phys. Rev. C 22, 750 (1980).

28. We thank G. R. Bauer and J. G. Moore, who provided assistance in the sample collection. This report benefited from review comments by l. Winograd and T. McConnaughey. We thank S. Allison for allowing us access to his property. This paper is a contribution to the LITE (Last Interglacial: Timing and Environment) project of the Global Change and Climate History Program of the U.S. Geological Survey.

17 May 1994; accepted 8 August 1994 